\title{
XXXI. On the electrical conductivity of copper fused with mica
}

\section{Sub-Lieut A.L. Williams R.N. \& Prof. J.C. McLennan F.R.S.}

To cite this article: Sub-Lieut A.L. Williams R.N. \& Prof. J.C. McLennan F.R.S. (1920) XXXI. On the electrical conductivity of copper fused with mica , Philosophical Magazine Series 6, 40:237, 281-290, DOI: $10.1080 / 14786440908636125$

To link to this article: http://dx.doi.org/10.1080/14786440908636125

曲 Published online: 08 Apr 2009.

Submit your article to this journal $\pi$

Џll Article views: 2

Q View related articles $₫$ 
XXXI. On the Electrical Conductivity of Copper fused with Mica. By Sub-Lieut. A. L. Williams, R.N., with Introduction by Prof. J. C. McLennan, F.R.S.*

[PIates V.-VII.]

INTRODUCTION.

WHILE acting as Scientific Adviser to the Admiralty, I had my attention drawn by Sub-Lieut. A. L. Williams, R.N., to some experiments made by him in the early part of 1919 at Cambridge, in which he found that samples of copper when fused with mica exhibited a remarkably large fall in resistance when gradually subjected to rising temperatures.

During a short furlongh he was given an opportunity at the Admiralty Physical Laboratory, South Kensington, to develop this discovery and, on going back to duty, he left with the some notes embodying the results of his work. I have not bad an opportunity of communicating with him again, but as the results are interesting it is thought they should be duly recorded. His experiments are described below, and accompanying them are some additional notes of results obtained at the University of T'oronto by Miss Isabel Mackey and Miss I. Giles, who have followed up the subject still further.

J. (). McI.

A.

Experiments by Sub-Lievt'. A. L. Williams, R.N.

\section{Preparation.}

The samples for test were all prepared in the open on a piece of iron or copper plate-used as an anode-and a carbon rod as the cathode, the arc being struck at first between the plate and carbon, and then, when hot, to the mixture. The mica was first melted, then the copper added. In making up the samples studied, about equal proportions of copper and mica were used.

\section{Efject of Temperature.}

Resistance temperature measurements for two samples were made for a range of temperatures from $27^{\circ}$ to $850^{\circ} \mathrm{C}$. For sample $A$, the curves of which are attached, Graphs 1 and 2 (Pl. V.), the resistance fell from $16,000 \mathrm{ohms}$ at $27^{\circ} \mathrm{C}$., to 0.5 ohm at $850^{\circ} \mathrm{C}$.

* Communicated by Prof. J. C. McLennan.

Phil. Mag. Ser. 6. Vol. 40. No. 237. Sept. 1920. 
III. Notes.

(1) It was noted that the material was malleable at about $2000^{\circ} \mathrm{C}$.

(2) A specimen piece was rolled at this temperature into a small rod $2.5 \mathrm{~mm}$. in diameter for the purpose of ascertaining the specific resistance of the mixture. This was found to be as follows:-

$$
\begin{aligned}
& 25^{\circ} \mathrm{C} \text {., Specific Resistance, } 10,400 \text { ohms. } \\
& 30^{\circ} \mathrm{C} \text {, " }, \quad 8,000 \text { ohms. }
\end{aligned}
$$

(3) An attempt was made to obtain a sample of the mixture in the form of a very thin film for delicate temperature measurements, etc., and it was found possible to squeeze it out to about $1 / 1000$ of an inch between platinum foil. It was not possible, however, to separate the film from the foil; but two pieces of foil cemented together by this fine film were found to be extremely sensitive to beat. They quickly responded to the action of infra-red rays from an arc about one yard away, notwithstanding the comparatively large volume of platinum to be heated first.

It is thought that with suitable films of the copper-mica mixtures enclosed in hydrogen it may be possible to use them for signalling purposes. It is also suggested that these films may be used instead of wires in microphones for soundranging, as the changes of resistance, due to changes of temperature, are quite considerable, being some thousands of ohms per degree centigrade with some samples.

(4) Attempts were made to make thin sheets by mixing the copper-mica material, finely powdered, with fine carbon, in the form of cane-sugar, and driving off the water by heating. The resistance of the resulting material was extremely high, but very regular thin sheets could be obtained in this way. It is possible, when the density of this mixture is increased by compression in an hydraulie press, that it may be obtained in sheets, rods, or other forms having a moderate resistance and yet possessing a high resistance-temperature coefficient.

5. Attempts to cast the material in various forms were not successful, partly owing to the difficulty in working with the requisite high temperatures. The material, when molten, is absorbed by such porous substances as porcelain, and if glazed porcelain is used the glazing melts and mixes with the material. It is possible that castings could be obtained by using fused quartz as a moulding material. 
6. Attempts were made to make up similar compounds with the following metals and mica:-

Tin. The metal vaporized at too low a temperature.

Silver. Did not combine.

Platinum. Did not combine.

Iron. Combined, but no resistance temperature measurements were made.

B.

Experiments by Miss Mackey.

I. Experimental Arrangements.

(a) The samples to be tested were all made in the open on a piece of iron plate used as an anode and a carbon rod as a cathode. The current was controlled by a large rheostat giving up to 30 amperes on the 110 D.c. circuit. An arc was struck between the plate and carbon and, when hot, the mica was melted and the other material added.

(b) A quartz tube closed at one end and covered with nichrome wire was used as a receptacle in which to melt the material and form it into a regular cylindrical shape for experimental work.

(c) A small electrical furnace was used to heat the material. It consisted of a circular porcelain foundation covered with wire and all was covered with asbestos except the two binding posts.

\section{Results.}

(a) Mica and Copper.-Mica and copper were fused on the iron plate into small lumps, and some of these were then finely ground into powder. No traces of mica or copper could be detected, only a uniform dull black powder. The powder was put into a quartz tube and heated, but this did not prove a satisfactory method of obtaining the mixture in the form of solid rods, as part of the mixture fused with the quartz, and it was found impossible to separate the two substances. When the quartz was broken, the copper-mica was found to be very brittle and not at all suitable for resistance measurements. Platinum wires were then fised into the ends of the copper-mica lumps which had not been powdered, and the variations in the resistances of these lumps were observed when they were raised to rarious temperatures. 


\section{Sub-Lieut. A. L. Williams on the Electrical}

Two different samples of copper and mica were tested in the furnace for variation in resistance with temperature (but only up to about $400^{\circ}$ C.). In Case No. 1 (Graph No. 3), the resistance was found to vary from $4400 \mathrm{ohms}$ to $300 \mathrm{ohms}$, while the temperature varied from $25^{\circ} \mathrm{O}$. to $400^{\circ} \mathrm{C}$. The specific gravity of the specimen was found to be $5 \cdot 1$, and as copper is given by $8 \cdot 9$, it will be seen that the specimen contained considerable mica.

Graph No. 3.

$\begin{array}{cc}\begin{array}{c}\text { Temperature, } \\ { }^{\circ} \mathrm{C} .\end{array} & \begin{array}{c}\text { Resistance } \\ \text { (Ohms) }\end{array} \\ 22 & 4,400 \\ 46 & 3,600 \\ 54 & 3,200 \\ 58.5 & 2,940 \\ 61 & 2,900 \\ 65.5 & 2,800 \\ 70 & 2,460 \\ 72 & 2,400 \\ 93 & 1,950 \\ 127 & 1,550\end{array}$

$\begin{array}{cc}\text { Tempernture, } & \text { Resistance } \\ \text { o C. } & \text { (Ohms) } \\ 148 & 1,250 \\ 154 & 1,150 \\ 164 & 1,100 \\ 206 & 780 \\ 260 & 611 \\ 275 & 450 \\ 315 & 400 \\ 344 & 340 \\ 364 & 281\end{array}$

In Case No. 2 (Graph No. 4) the variation in resistance was from 95,000 ohms to 3000 ohms, while the temperature changed from $100^{\circ} \mathrm{C}$, to $400^{\circ} \mathrm{C}$. The specific gravity was found to be $4 \cdot 3$.

\section{GrapH No. 4.}

$\begin{array}{cc}\begin{array}{c}\text { Temperature, } \\ { }^{\mathrm{C}}\end{array} & \begin{array}{c}\text { Resistanee } \\ \text { (Ohms). }\end{array} \\ 139 & 45,550 \\ 178 & 23,330 \\ 236 & 11,645 \\ 262 & 9,120 \\ 314 & 6,000 \\ 345 & 4,590 \\ 364 & 3,790 \\ 378 & 3,605 \\ 395 & 3,280 \\ 333 & 4,200 \\ 323 & 4,740 \\ 313 & 5,490 \\ 290 & 6,330 \\ 278 & 7,030 \\ 267 & 7,790 \\ 256 & 8,610 \\ 245 & 9,410 \\ 232 & 10,790\end{array}$

$\begin{array}{cc}\begin{array}{c}\text { Tempersture, } \\ { }^{\circ} \mathrm{C} .\end{array} & \begin{array}{c}\text { Resistance } \\ \text { (Ohms) }\end{array} \\ 228 & 11,370 \\ 211 & 13,585 \\ 208 & 14,570 \\ 200 & 167738 \\ 192 & 19,090 \\ 172 & 23,445 \\ 165 & 26,230 \\ 155 & 29,670 \\ 147 & 34,050 \\ 139 & 40,505 \\ 130 & 44,350 \\ 122 & 51,340 \\ 118 & 57,110 \\ 113 & 64,070 \\ 108 & 74,033 \\ 103 & 81,740 \\ 99 & 91,010\end{array}$

From these results it would appear that an increase in the mica-content of the mixture raises the resistance at ordinary. 
temperature and causes the fall in resistance with temperature to be much more rapid.

While more brittle than copper, the copper-mica is not as brittle as iron-mica compounds described below. The hardness is almost the same as that of glass. X-ray photographs showed the composition to be quite homogeneous. The mixture was black with a dull metallic lustre.

(b) Iron and Mica.-Two mixtures were made as in the case of the copper and mica, and the temperatures and resistances were measured as before. In Case No. 1 (Graph No. 5) the resistance fell from $1300 \mathrm{ohms}$ to $100 \mathrm{ohms}$ on being heated from $25^{\circ} \mathrm{C}$. to nearly $300^{\circ} \mathrm{C}$.

\section{Graph No. 5.}

Temperature, Resistance

${ }^{\circ} \mathrm{C}$.

26

42

475

525

54

104

134

138

178

195

209

218

165

214

263

282

294
(Obms).

1,350

980

890

825

790

410

350

340

219

180

160

150

280

170

115

$10: 3$

95
Temperature, Resistance ${ }^{\circ} \mathrm{C}$ (Ohms).

303

308

165

$138 \quad 310$

$116 \quad 380$

$97 \quad 490$

$75 \quad 650$

$83 \quad 590$

$64 \quad 765$

$55 \quad 860$

$51 \quad 905$

$45 \quad 1,010$

$40 \quad 1,070$

$38 \quad 1,110$

3351,203

$31 \quad 1,240$

In Case No. 2 (Graph No. 6) the resistance fell from 32,000 olhms on being heated from $160^{\circ} \mathrm{C}$. to $380^{\circ} \mathrm{C}$.

GrapH No. 6.

\begin{tabular}{cc|cc}
$\begin{array}{c}\text { Temperature, } \\
{ }^{\circ} \text { C. }\end{array}$ & $\begin{array}{c}\text { Resistanee } \\
\text { (Ohms). }\end{array}$ & $\begin{array}{c}\text { Temperature, } \\
\text { o C. }\end{array}$ & $\begin{array}{c}\text { Resistance } \\
\text { (Obms) }\end{array}$ \\
250 & 6,100 & 294 & 3,380 \\
228 & 9,050 & 282 & 3,900 \\
280 & 3,870 & 255 & 5,970 \\
318 & 2,410 & 242 & 7,350 \\
335 & 1,980 & 231 & 8,440 \\
344 & 1,780 & 222 & 10,380 \\
360 & 1,550 & 214 & 11,720 \\
377 & 1,280 & 204 & 15,750 \\
360 & 1,550 & 197 & 15,900 \\
336 & 1,989 & 187 & 19,550 \\
322 & 2,360 & 175 & 25,210 \\
309 & 2,730 & 164 & 32,100
\end{tabular}


The hardness was above that of glass, and the material was much more brittle than copper-mica and had more metallic lustre. X-ray examinations showed the mixture to be homogeneous. The specific gravity in Case No. 1 was $3 \cdot 7$, and in Case No. 2 was 4 . The specimens studied were quite irregular in shape, but from a rough examination of the sizes of the samples, it appeared that the sample which had the higher mica-content was the one which had the higher specific resistance.

(c) Aluminium and Mica. - No fusion was obtained between aluminium and mica. The two seemed to remain entirely separate.

(d) Antimony and Mica. - The antimony when heated gave off dense clouds of vapour, leaving nothing to fuse with the mica.

(e) Bismuth and Mica.-The same results were obtained as with antimony.

(f) Colvalt and Mica.-Cobalt and mica were fused on the iron plate in the same manner as the copper and mica. The cobalt-mica had a very dull black colour and was very brittle, but hard enough to scratch glass. Platinum wires were fused in the ends with difficulty, and the resistance at ordinary temperatures was very great. When heated red hot with a bunsen flame, a current of about 020 ampere was obtained, using the 110 circuit.

(g) Nickel and Mica.- When nickel and mica were fused, the substance produced was very similar to cobalt-mica. When it was heated red hot, a current of about 001 ampere was obtained, using the 110 circuit.

(h) Manqanese and Mica.-Mica and manganese did not seem to mix at all. In one test, the manganese was found to form a complete shell around the mica, and in other casea an X-ray photograph showed the two to be quite separate.

(i) Silicon and Copper.-It did not seem at all easy, if indeed possible, to fuse copper and silicon. The two substances appeared to be quite separate after fusion.

(j) Selenium and Copper.-These fused quite readily and formed a dull black substance with very little or no lustre. The resistance was found at various temperatures and a graph, No. 8, drawn. The specific gravity was 6.6 , and the hardness less than that of glass. With this mixture it will be seen that a discontinuity occurred in the resistance temperature measurements at about $150^{\circ} \mathrm{C}$. The explanation of this result does not appear evident at present. 
Graph No. 8.

\begin{tabular}{|c|c|c|c|}
\hline $\begin{array}{c}\text { Temperature; } \\
{ }^{3} \mathrm{C} .\end{array}$ & $\begin{array}{c}\text { Resistance } \\
\text { (Ohms). }\end{array}$ & $\begin{array}{c}\text { Temperature, } \\
{ }^{\circ} \mathrm{C} .\end{array}$ & $\begin{array}{l}\text { Resistance } \\
\text { (Obuns). }\end{array}$ \\
\hline 370 & $\cdot 219$ & 124 & .261 \\
\hline 335 & .207 & 115 & .200 \\
\hline 315 & .200 & 108 & $\cdot 176$ \\
\hline 298 & $\cdot 188$ & 104 & $\cdot 172$ \\
\hline 260 & $\cdot 173$ & 101 & $\cdot 169$ \\
\hline 247 & $\cdot 164$ & 98 & $\cdot 169$ \\
\hline 240 & .164 & 95 & $\cdot 168$ \\
\hline 230 & $\cdot 162$ & 92 & $\cdot 163$ \\
\hline 221 & $\cdot 157$ & 90 & $\cdot 164$ \\
\hline 204 & $\cdot 152$ & 87 & $\cdot 164$ \\
\hline 190 & $\cdot 147$ & 84 & $\cdot 163$ \\
\hline 180 & . 1399 & 80 & $\cdot 165$ \\
\hline 173 & $\cdot 136$ & 78 & .167 \\
\hline 167 & $\cdot 136$ & 65 & $\cdot 176$ \\
\hline 160 & $\cdot 135$ & 61 & .176 \\
\hline 154 & .130 & 59 & .177 \\
\hline 136 & $\cdot 333$ & 58 & $\cdot 176$ \\
\hline 130 & .317 & 44 & $\cdot 185$ \\
\hline 127 & .300 & & \\
\hline
\end{tabular}

(k) Ferro-Silicon.-A sample of commercial ferro-silicon was also investigated. It was found to be very brittle and difficult to grind up into regular form for examination. In studying a sample, leading wires of iron were used, as platinum fused readily at the junction when the ferro-silicon was raised to a high temperature. When a graph was drawn between temperatures as abscissæ and resistance as ordinates, the result was a straight line showing that the resistance varied directly as the temperature, just as in the case of ordinary pure metals. (See Graph No. 7.)

\section{Graph No. 7.}

$\begin{array}{cc}\text { Temperature, } & \begin{array}{c}\text { Kesistance } \\ \text { (Ohms relative) }\end{array} \\ 280 & .092 \\ 280 & .089 \\ 259 & .088 \\ 246 & .085 \\ 226 & .084 \\ 214 & .083 \\ 202 & .082 \\ 185 & .081 \\ 176 & .079 \\ 165 & \end{array}$

$\begin{array}{|cc|}\begin{array}{c}\text { Temperature, } \\ { }^{\circ} \mathrm{C} .\end{array} & \begin{array}{c}\text { Resistance } \\ \text { (Ohms relative) }\end{array} \\ 148 & .078 \\ 139 & .077 \\ 126 & .076 \\ 118 & .075 \\ 109 & .074 \\ 96 & .073 \\ 84 & .071 \\ 79 & .070 \\ 71 & .070\end{array}$

C.

Experimen'ts by Miss Gilfs.

In these experiments a micrographic study was made of the plane polished surfaces of the fused copper-mica mixtures referred to above. These were made both when the mixtures 
were at room temperatures and when their temperature was gradually raised by means of an electric furnace. The object in view was to see whether the fuser mixtures possessed any crystalline structure, and if they did whether the increased conductivity observed with them on raising their temperature could be connected in any way with observable modifications in their crystal structure.

\section{Preparation of Specimens.}

In preparing these specimens they were first of all filed off to an approximately flat surface. The surfaces were then ground on a carborundum wheel, and after that on several successive grades of aloxite of increasing fineness. The grades used were those commercially known as Nos. 90, 150, 220 , and $3 \mathrm{~F}$ respectively. The polishing was then started with optical alundum and finished with jewellers' rouge. The two coarsest grades of aloxite were used on a flat metal plate, while the finer grades and the optical alundum were used on fine even linen fabric stretched over a smooth glass plate. The rouge was used on a piece of soft, smooth broadcloth stretched over a glass plate. The plates used were fastened on a horizontal revolving table rotated by a small electric motor. In some cases the surfaces were etched with nitric acid of various concentrations ranging from strengths of 10 per cent. to 25 per cent. and even to 50 per cent. Better results, however, were obtained by the use of ammonia in solution, with a specific gravity of about 0.93 . With this solution the specimens were found to be uniformly etched by an attack of about one hour.

\section{Optical Equipnent.}

The microscope used was one of the instruments especially designed by Bausch and Lomb for micrographic work. For normal illumination the type of illuminator used was the usual reflecting disk of thin cover glass. In this methor the light was projected at right angles to the optical axis of the microscope, reflected from the cover glass alonir the optical axis of the system to the specimen, and then back through the microscope. For visual examination the source of light was a frosted electric light bulb, while for the photographic work a small carbon arc was used. The photographic plates used were rapid panchromatic, and the shorter wavelengths in the illuminating beam were cut out with a Wratten and Wainwright filter. Oblique, in place of normal illumination, was used in some cases. 


\section{Results.}

When examined under the microscope different specimens were found to exhibit different appearances. Most samples appeared to be quite uniform in structure, while in some many little globules could be seen, which from their lustre appeared to be pure copper.

Specimens which possessed a high temperature coefficient were found both under high and low power magnification to show no change in structure, either by normal or oblique illumination, when heated to temperatures as hi, h as $400^{\circ} \mathrm{C}$.

Pl. VII. fig. 1 shows the appearance of a specimen at room temperatures with a magnification of 46 . The resistance of this sample, which was $3200 \mathrm{ohms}$ at $21^{\circ} \mathrm{C}$., fell to 1600 when at $95^{\circ} \mathrm{C}$. The structure of the specimen appeared very uniform, and no copper could be discerned in it judging by metallic lustre.

Pl. VII. fig. 2 shows the appearance of this specimen when etched with ammonia solution for an hour. As pure copper was found to require approximately about seven hours' exposure to ammonia to bring out its crystalline structure, the markings on the plate may be taken to indicate the boundaries between copper and mica or the constituents of the latter. The regularity of the markings would indicate that the copper and mica fused into an intimate and homogeneous mass.

A specimen, whose resistance at $100^{\circ} \mathrm{C}$. was found to be 95,000 ohms and only $3000 \mathrm{ohms}$ at $400^{\circ}$ (., was polished and examined previous to etching it with ammonia, both with high-power and low-power magnification, and with oblique and direct illumination.

Pl. VII. fig. 3 shows its appearance whell illuminated obliquely under a magnification of 46 .

Pl. VII. figs. $4 \& 5$ show the same region when illuminated by normally reflected light under magnifications 46 and 205 respectively. The structure in this case, as will be seen, is quite different from that shown in Pl. VIJ. fig. 1.

With the sample illustrated by figs. 3,4 , and 5 there appeared to be a great many streaks of light and dark, bounded by straight lines running in all directions, while in other specimens there appeared to be nothing uniform in the shapes of the patches. The portions of the surface which are dark in Pl. VII. fig. 3 it will be seen are light in Pl.VII. fig. 4. In this specimen much detail was brought out with the low-power objective. It was therefore used among others with low magnification to study the effect of any increase in temperatures. A water-cell provided with 
running water was placed between the specimen and the microscope objective, in order to cut off the heat from the objective, and the specimen was heated up to $400^{\circ} \mathrm{C}$. No change could be discerned in the appearance of the etching.

Pl. VII. fig. 6 shows the appearance of a portion of the surface at a temperature of $350^{\circ} \mathrm{C}$.

The specimen was then etched with the ammonia solution. Here, again, the surface was found to be marked by fine lines after an attack of about an hour, but no copper could be letected. It was heated again to $400^{\circ} \mathrm{C}$. after etching, but no change in structure could be observed due to the rise in temperature.

\section{Resistance-temperature coefficient of Glass.}

In studying these specimens, one gained the impression that they possessed a number of the characteristics of glass. In most cases the specimens were very hard, and one could easily produce scratches on a glass plate with many of them. It is known, too, that many glasses when strongly heated become electrically conducting, and with a viow of making a comparison between the behaviour of these specimens and that of a sample of glass, some measurements were made on the resistance of a rod of glass when its temperature was gradually raised.

In these experiments a rod of "Schmeltzglas" about $8.0 \mathrm{~cm}$. long and $5.0 \mathrm{~mm}$. in diameter was used. Short platinum wires were attached. These were then joined in circuit with the mains of the 110 volt D.c. circuit, and the glass portion was placed within an electric furnace. As the temperature rose observations were made on the current which passed and on the fall of potential between the ends of the glass rod, contact being made with the circuit at the platinum junctions.

In these observations practically no current was found to pass through the glass until a temperature of about $300^{\circ} \mathrm{C}$. was reached. Even then the current was only of the order of $10^{-7}$ ampere, which showed that the resistance of the glass rod at this temperature was very high, practically about $10^{9} \mathrm{ohms}$.

From this result it would appear that the high resistance temperature coefficient possessed by the fused copper-mica mixtures is something specific, and it does not appear that the remarkable property they exhibit finds a direct parallel in the behaviour of glass.

The Physical Laboratory. University of Toronto, Nay 15 th, 1920. 
Graph Nol.

COPPER - MICA
RESISTANCE-TEMPERATURE CUIS
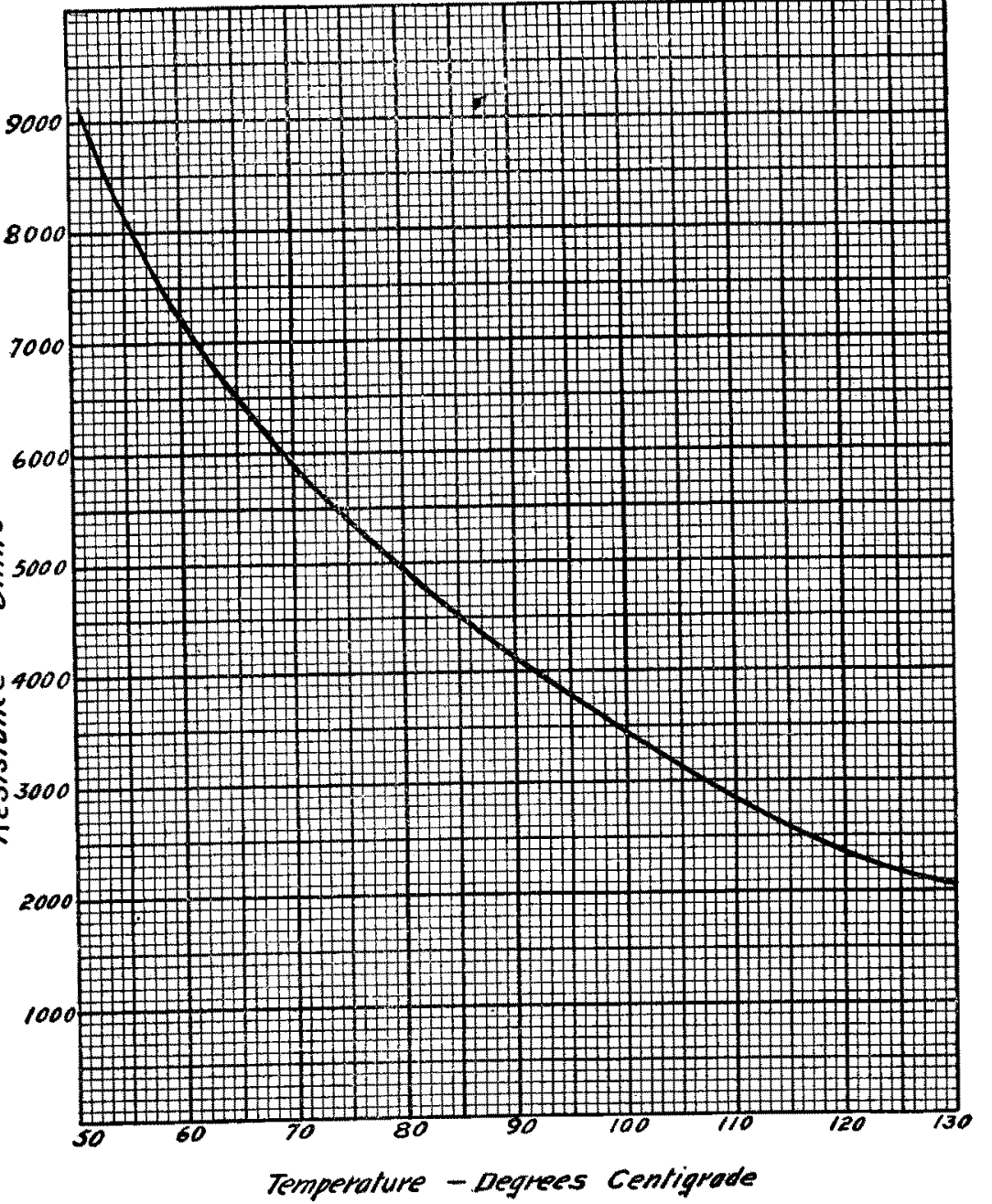

Graph Ne2

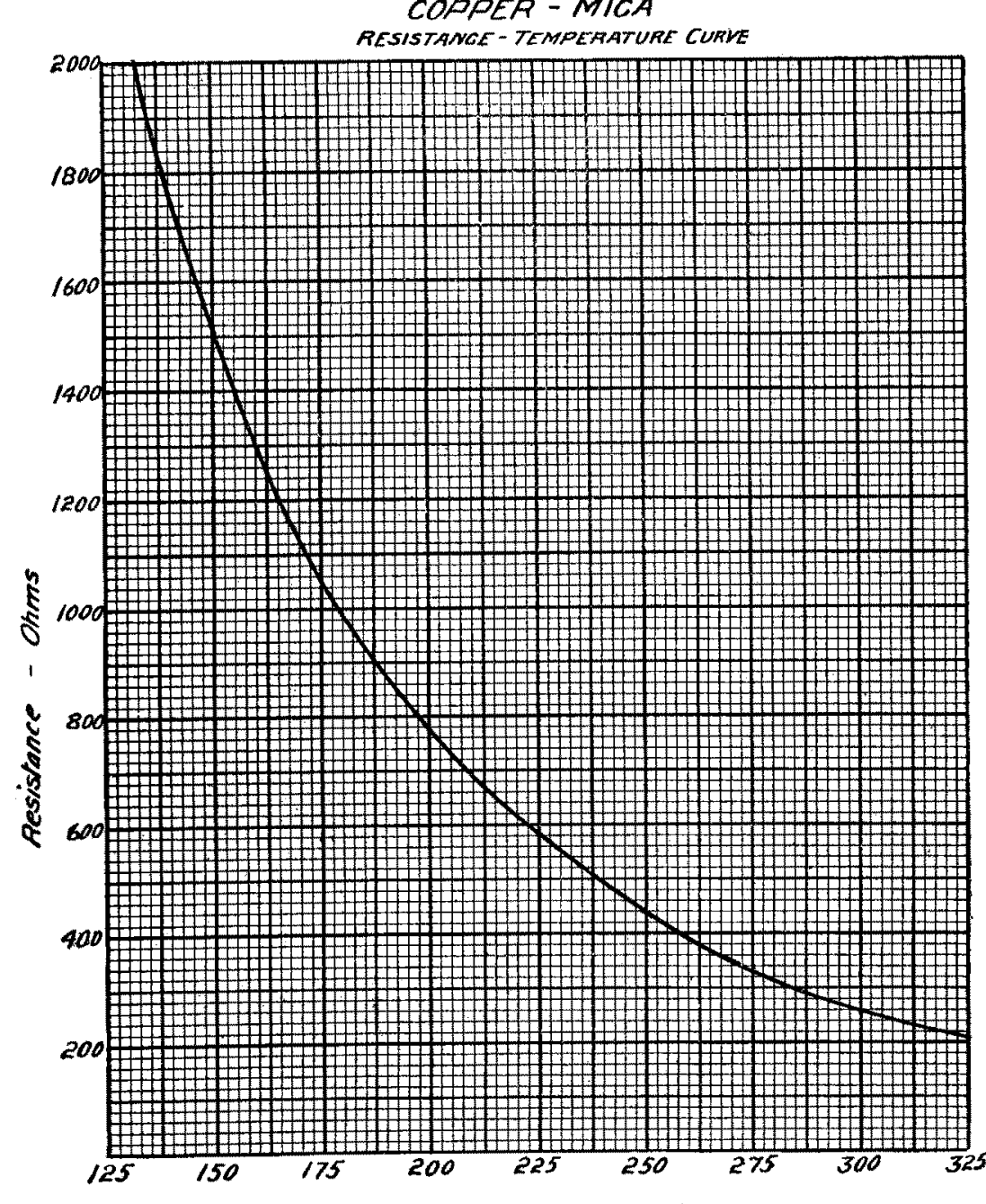

Temperature - Degrees Centigrade.
Groph N: 3

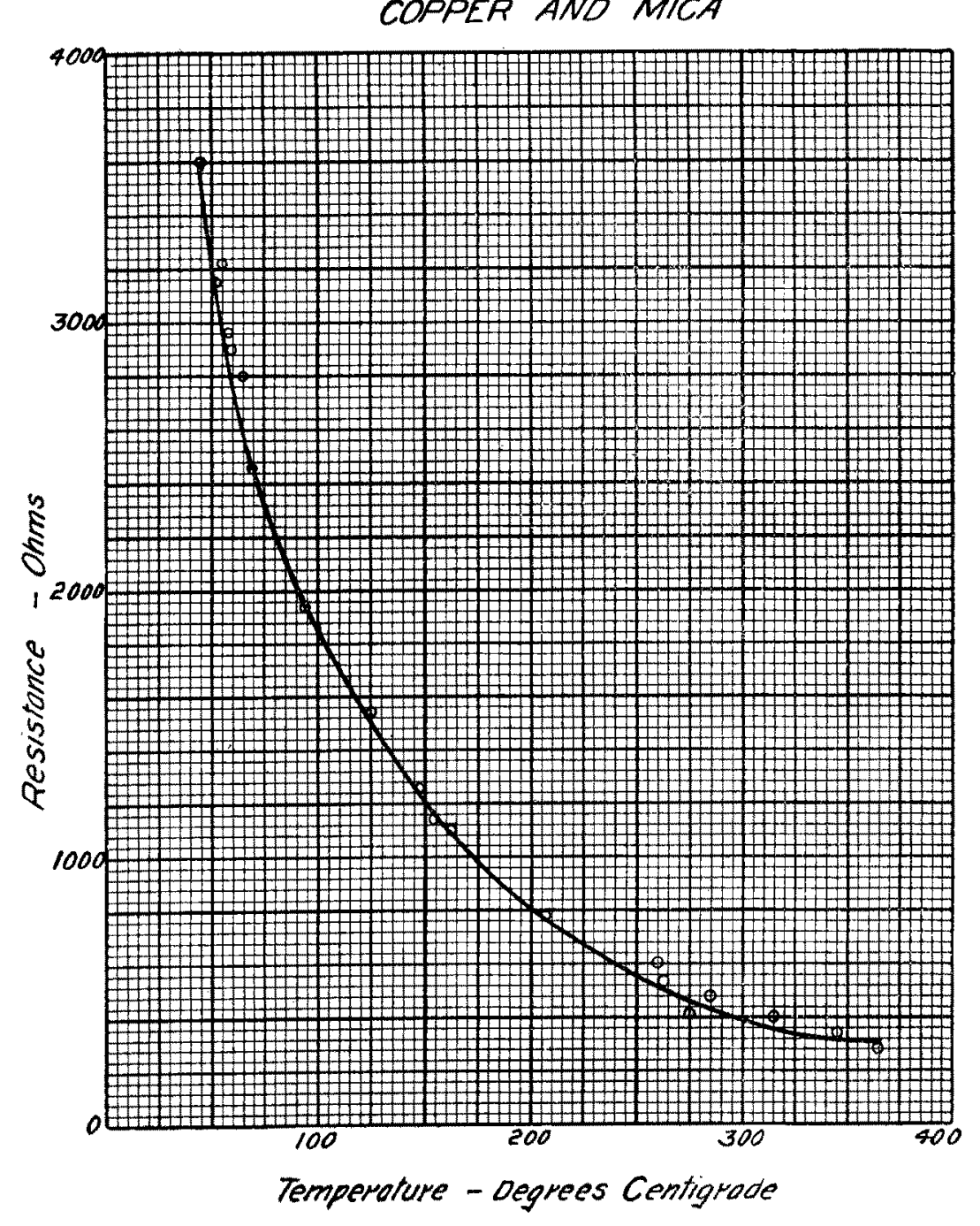

Groph NO
COPPEP AND MICA

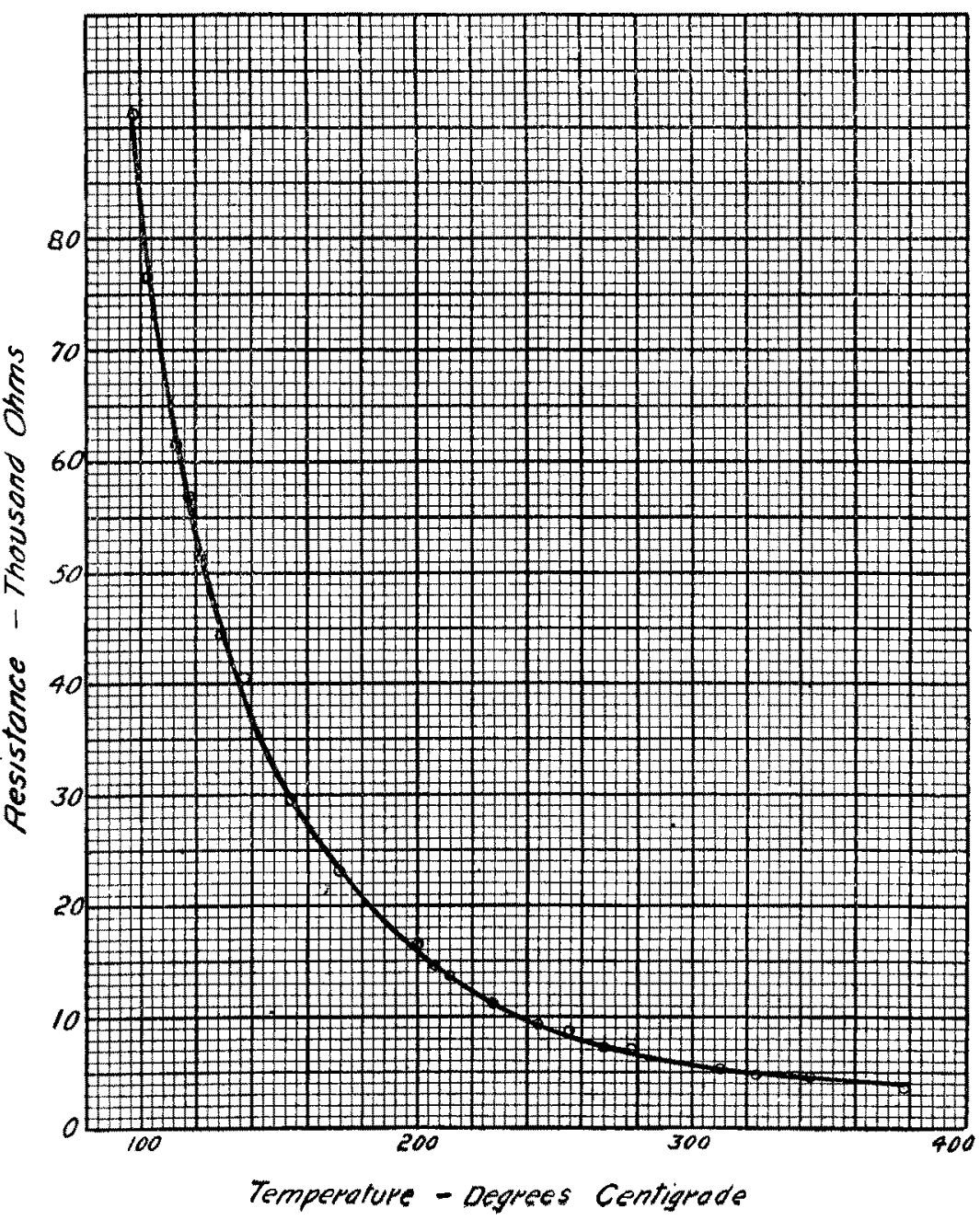


Graph NO 5
IRON AND MICA

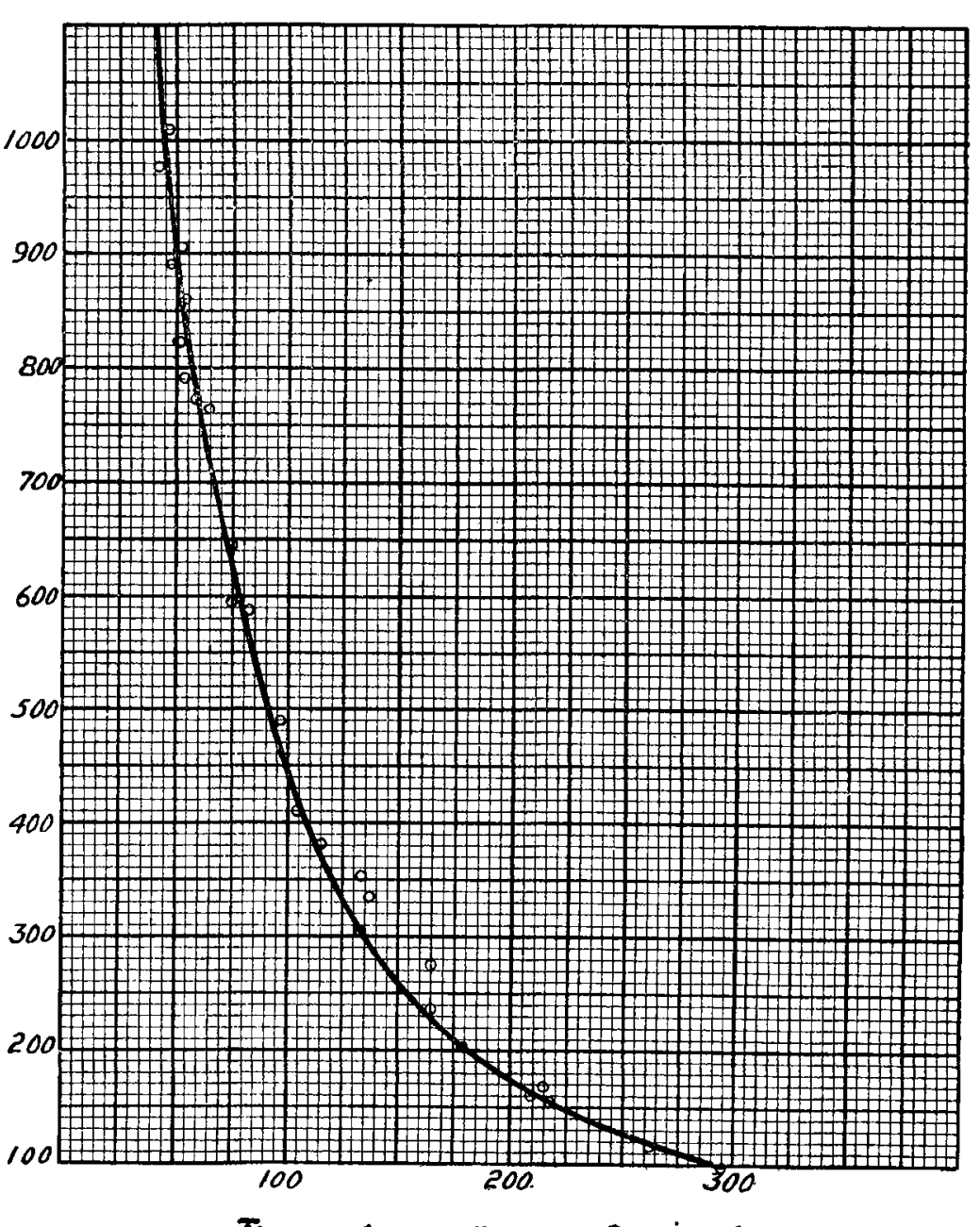

Temperarure - Degrees Centigrede
Graph No 6

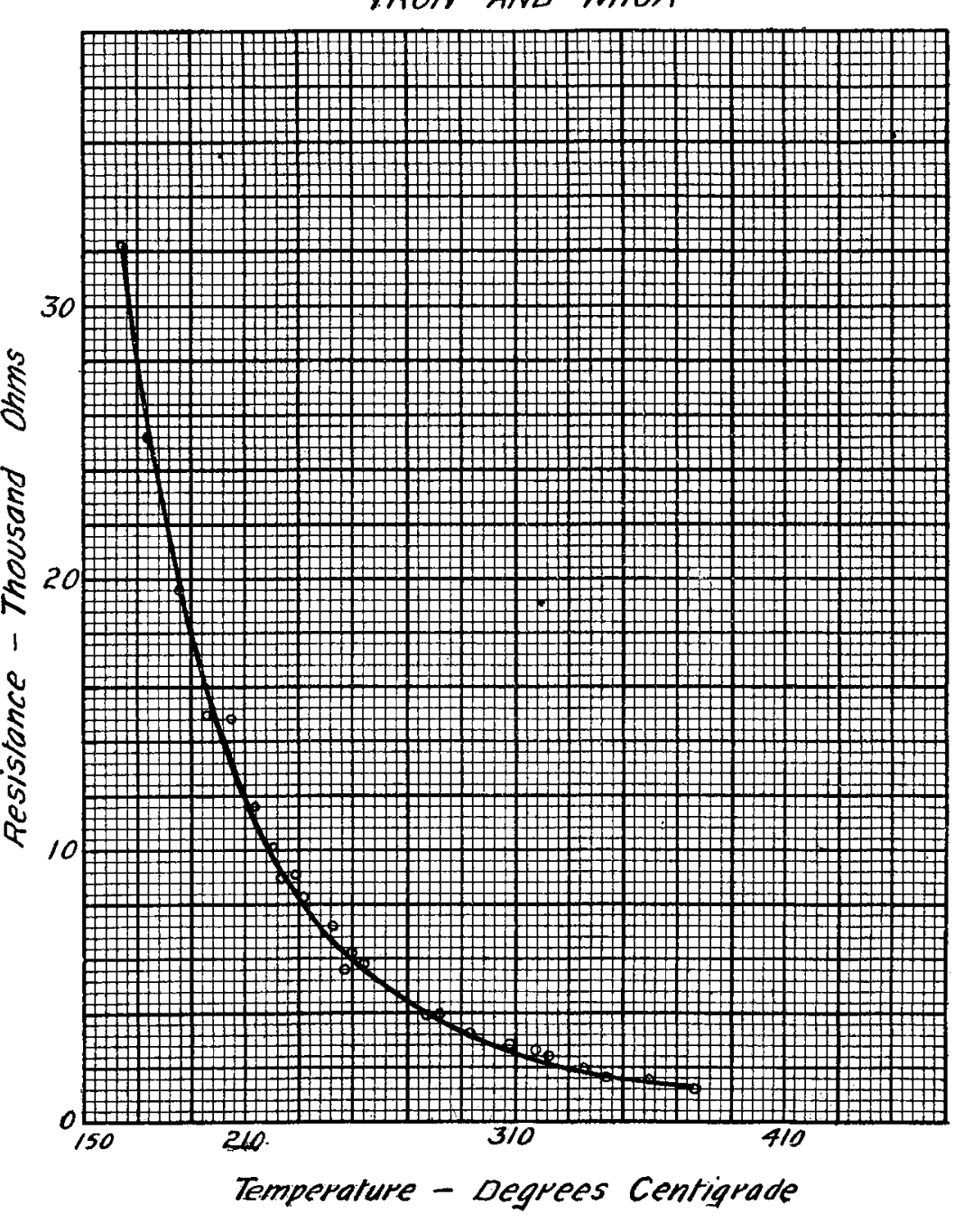

Groph No 7
EEROO-SIUCON

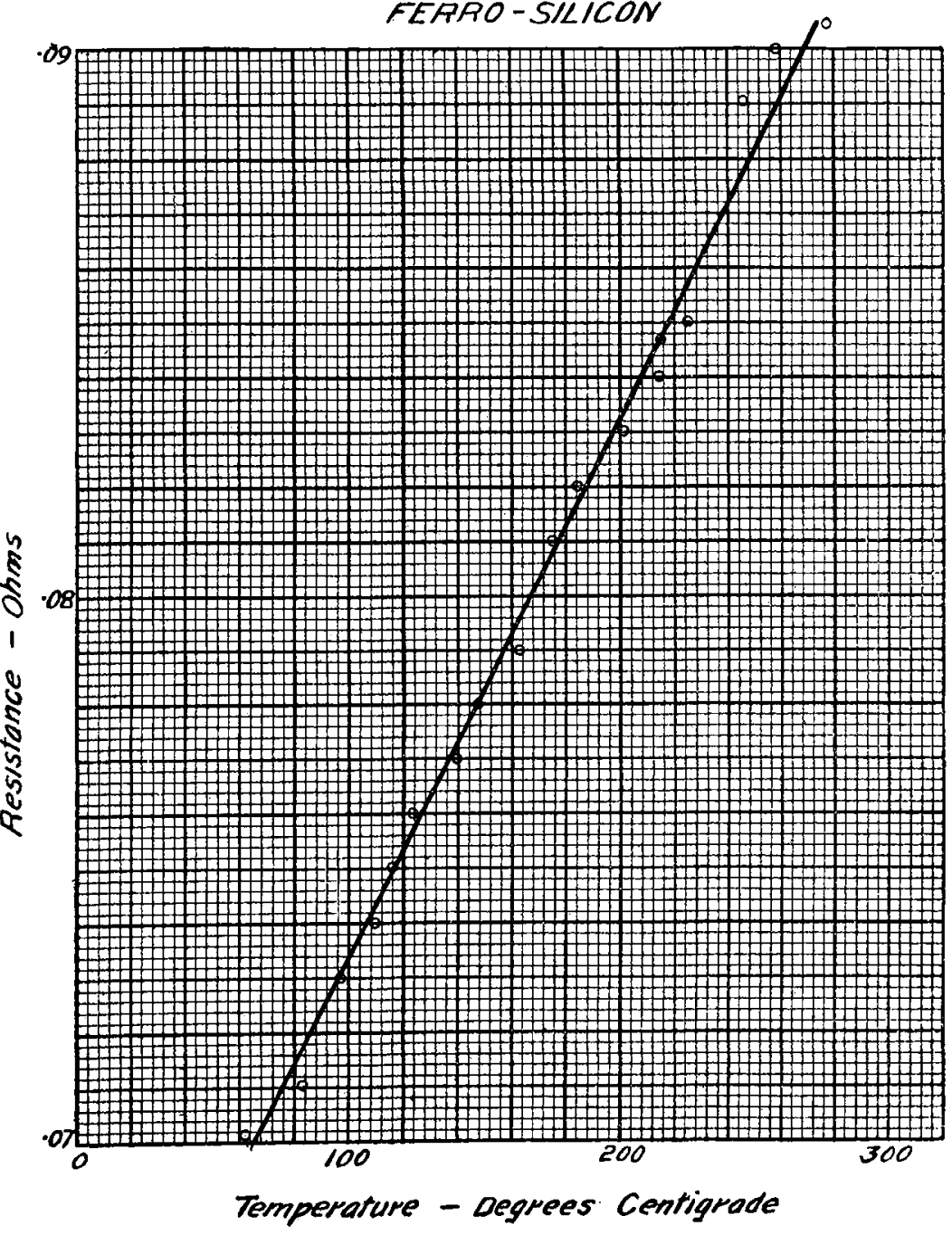

Graph No 8

COPPER AND SELENIUM

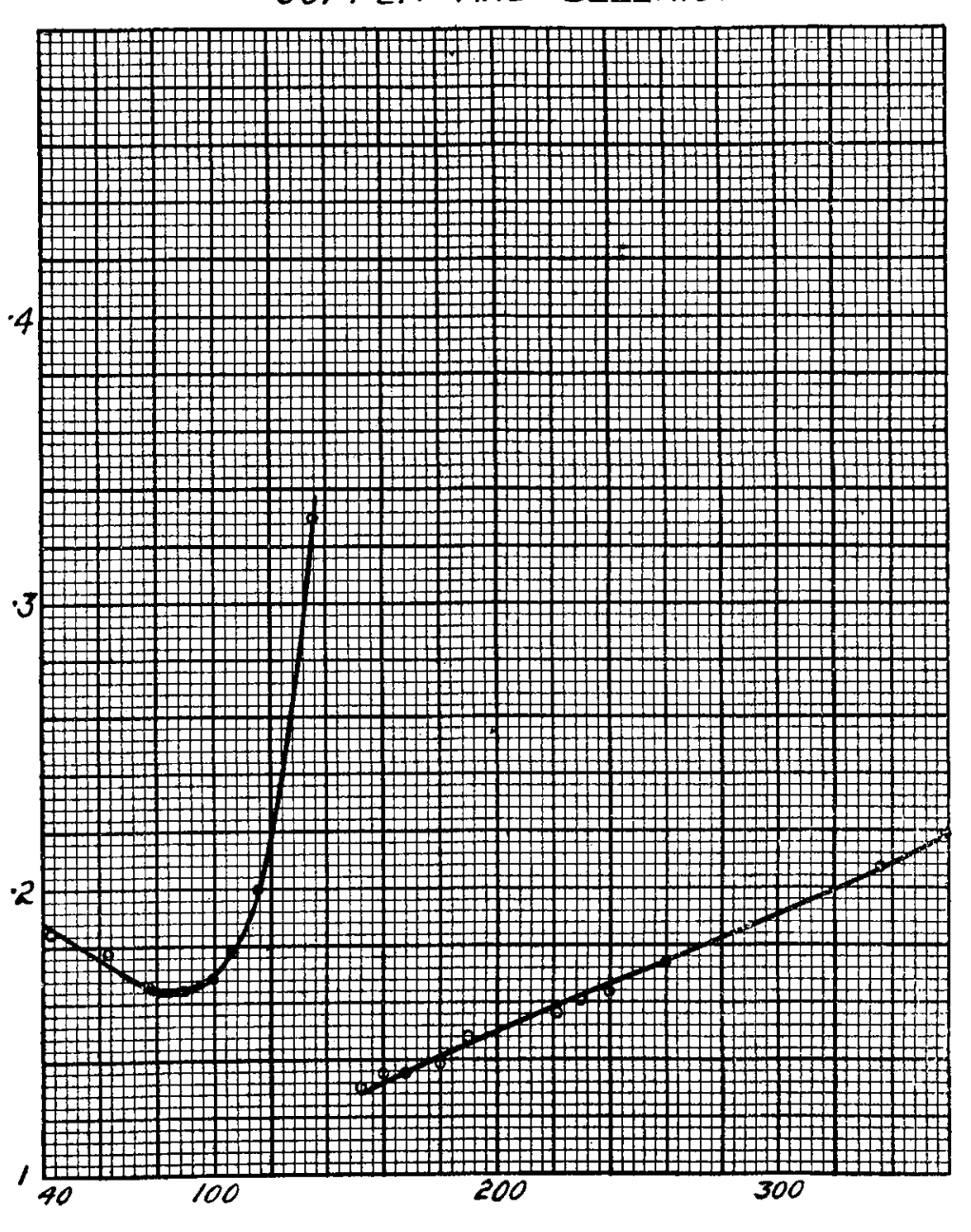

Temperature-Degrees Centigrade 


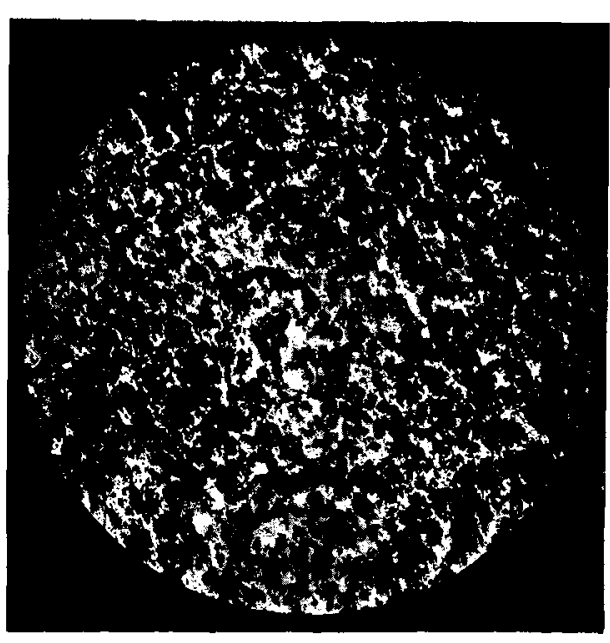

1

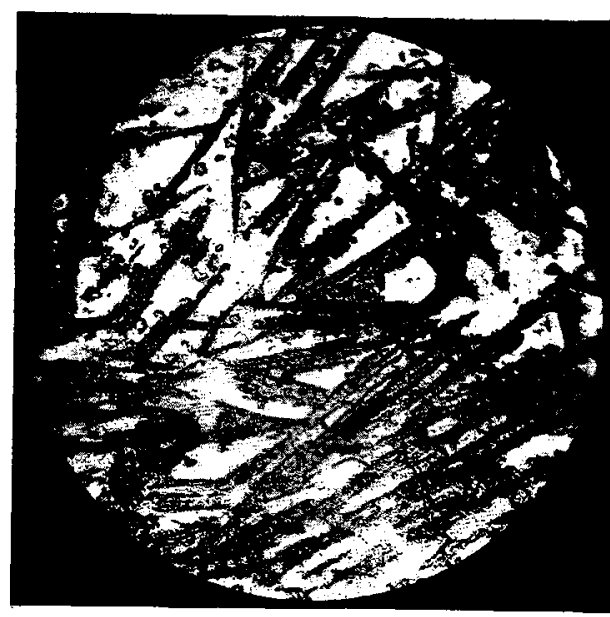

4

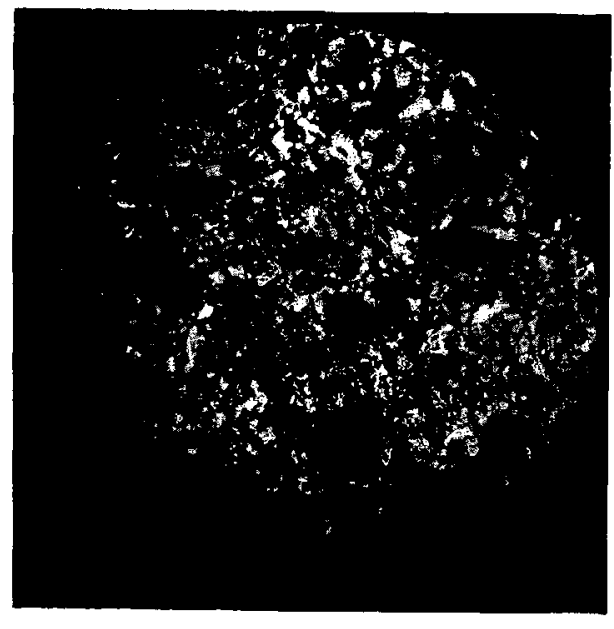

2

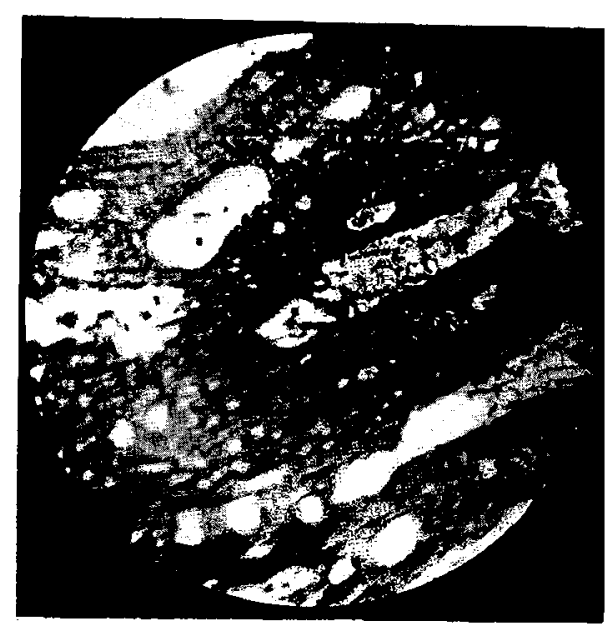

5

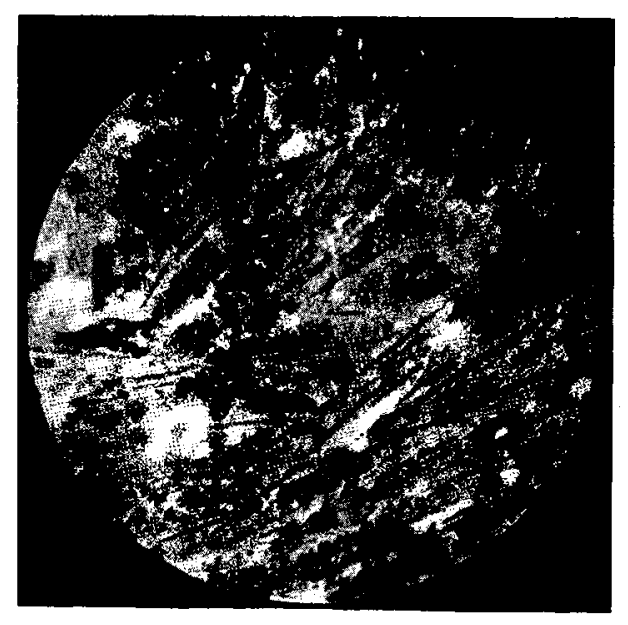

3

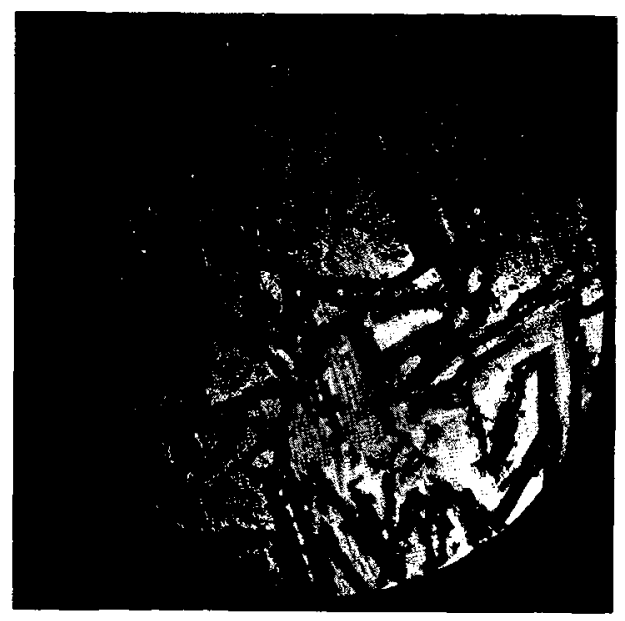

6 